\title{
The Role of Judiciary in Promoting Sustainable Development: Need of Specialized Environment Court in India
}

\author{
Km. Saroj Gupta \\ Research scholar, Nehru gram Bharati University \\ Kotwa-jamunipur, Allahabad, Uttar Pradesh, India \\ Administrative office-12, park street, New Delhi, India \\ Telefax: 011-23094091Ｅ-mail: Sarojgupta1886@gmail.com
}

Received: October 19, 2010

Accepted: January 10, 2011

doi:10.5539/jsd.v4n2p249

\begin{abstract}
Sustainable development is increasingly promulgated in international and national legal contexts, but there is a long way to go in terms of implementation. The role of the judiciary is thus of the greatest importance. The judiciary, at a national level, is faced with the task of explicating the law of sustainable development, case by case. Incrementally a body of environmental jurisprudence is emerging. In performing this task, national judiciaries will be assisted by the exchange of judicial decisions, information and experience between jurisdictions. In this way, national judiciaries may benefit from each other's knowledge, experience and expertise. The purpose of this article is to contribute to this information-sharing goal. The author's argument is that, prerequisites for establishing special environmental court in India are not available, and a full review for the Indian environmental legislations and judicial structure is needed before deciding the issue of establishing special environmental court.
\end{abstract}

Keywords: Sustainable Development, Role of the Judiciary, Environment court, Environmental law

India has a comprehensive environmental framework with an extensive set of environmental laws; Statutory mandates, regulatory instruments and institutional frameworks to implement and enforce Environmental policy objectives. The case for establishing an environmental court in India increasingly became an interesting issue; over the last few decades India witnessed huge changes that affect all most every aspect of human life.

Apart from the natural factor, political instability in the region which caused many Environmental problems. India is a Democratic country and a big population problem and flexible law of environment creates a slow process to solve major cases.

Therefore, protection of the environment is hoped to be on the top of the States priorities to Achieve sustainable development and maintain the natural environmental balance.

There are a lot of examples such as-Kautilya, the Prime Minister of Magadha, during the regime of Chandra Gupta Maurya, 300 B.C. in his 'Arthshastra' exhaustible dealt with the question of environment protection. He laid down the rules for protection and up gradation of environment minutely, meticulously and with great Details. Mauryan King Ashoka depicted exemplary compassion for wildlife and prohibited killing certain species of creatures. We find the preaching of compassion towards nature in all religions. "Don't make mischief in the earth" say holy Quran. Gautama Buddha's Religion was based on experience and logic. He believed on evolution of man. In the contemporary period Sikhism teaches that the life is made of five basic elements i.e. Earth, air, water, fire and sky. The colonial rule, however, disregarded ancient prudence, cultivated ruthless intelligence to exploit the environment for their material gain. (Environmental Protection Law \& Policy in India; Kailas Thakur; 2007 Edition 3).

\section{Sustainable Development \& Role of the Judiciary}

In 1972, 113 nations of the world gathered in Stockholm, Sweden. They were Concerned, the much-vaunted goal of economic growth had brought prosperity and High standards of living. But it had also brought unwanted spillover effects. The Land, air and waters of the world were being polluted to a dangerous level. The Natural resources were being exploited unsustainably.

The judiciary is also a crucial partner in promoting environmental governance, upholding the rule of law and in ensuring a fair balance between_Environmental, social and developmental consideration through its judgments and declarations. The role of the legal system to ensure environmental justice is only effective if it is universally 
accessible. The ability to develop democracy and civil political participation exists where the system of access is fair, and does not directly or indirectly exclude specific individuals, groups or organizations. Thus, there should be a better law for sustainable development, to save our common future.

\section{Present study-Introduction to the Need of Separate \& Specialized environment court}

The Importance of Environmental Courts as envisaged by the Supreme Court. At this point of time we have 29,315 pending cases in the Supreme Court, 32, 24,144 cases.in various High Courts and over 2, 53, 50,570 in various subordinate courts. By the time you finish reading this sentence hundred more would have been filed. Under these tons of various cases it is of utmost importance to treat environmental cases. Considering the fact that the everyday of pendency of the case means greater loss to the ecology.

Hence we are of the opinion that in order to deal with this anomaly the constitution of specialized 'environmental courts' is very essential. To start with this paper in Environmental

Law dealing with the need of Specialized Environmental courts to suit the needs of the country. Establishing Environmental Courts which would have the benefit of expert advice from environmental scientists/technically qualified persons, as part of the judicial process.

\section{Why Environmental Court is Necessary?}

The debate over the issue of establishing special environmental court in India is getting more serious. Advocates for the environmental courts establish their case on the following legal shortcomings associated with the current situation: Access to environmental justice is not sufficient and sometimes not exists at all because the traditional rules of civil or criminal litigations prevent interests groups or NGOs from bringing an action against polluters when their activities caused ecological damage per se.Under the Indian Civil Procedures Act, the admissibility of a civil action is to be considered according to certain requirements.

\section{Environmental Justice in India}

Environmental rights in India do not really exist in written form. They were rather created from lawyers and activists from other available resources. At first, the general provisions should be introduced before examining how the Indian Courts have decided on environmental related grievances. The analysis will be limited on constitutional rights.

\section{Prerequisites for Environmental Court}

Having special courts is not always an advantage; the ordinary judicial system should be the general rule of adjudication, whereas special courts are exceptions that must be justified by necessities. In my opinion, the first step towards setting up a special environmental court is to invest in training and qualifying prosecutors, judges, experts, and lawyers, so as to provide them with basic knowledge and skills which help them to deal effectively with environmental

Litigations. In the case of India, I do think that India has to decide the issue of establishing special environmental court after having the following prerequisites:

- Constitutional protection for the environment

- Better environmental legislations

- Improving environmental awareness

- Qualified judges for dealing with environmental litigations

\section{Qualified Judges for dealing with Environmental Litigations}

In the current situation, environmental litigation and environmental offenses are to be reviewed by ordinary courts, and mentioned above, judges in these courts have jurisdiction to review all cases of different types. This situation leaves ordinary courts with huge bulk of litigations, and little chance to specialize in a certain type of litigations. For satisfactory and effective environmental litigation, India needs to train a group of judges, lawyer and experts to deal with environmental litigations and offices and to set suitable training programs for this end. Needless to say that, this task is necessary even in the case that India does not establish special environmental court.

\section{Aim of study}

To access the Frequency, percentage and mean of judiciary experts' agreement for the items related to specialized environmental courts. 


\section{Methodology}

The evaluation study was carried out by feedback survey method. Some of the items in questionnaire were in Likert type five point agreement scale varying from strongly Disagree (1).to strongly agree (5).a holistic approach is followed in the feedback study which considers the involvement of learners as well as lawyers involved in the decision of judiciary in India. The category of layers included peers, and experts involved in the transaction of similar type of process. Two types of questionnaires were designed; one of the lawyers and other common for the experts, peers and others. The questionnaire for learners consisted of items related to the different cases, case background, case decision, process while the other one was mainly on the content (adequacy of illustration, coverage, self assessment, and question).the number of cases enrolled on an average for the decision is about 750.considering that the cases in 10 years time would be around 7, 500, a random sample of 700 cases (keeping in the mind the geographical distribution) were sent the questionnaire by mail. A total of 105 responses were received with a response rate of $15 \%$.the questionnaire meant for lawyers was posted to the different courts to be filled in by the experts involved in taking the counseling session for the cases. In addition a total of 10 experts working in different courts were contacted for giving a feedback on the cases. Along with the formal feedback through questionnaire, informal discussions with a number of peers in the discipline were also carried out in order to gauge the level and adequacy of the green courts in India. The feedback data was analyzed mainly by calculating the percentage and mean for some of the items.

\section{Sample Characteristics}

One of the total respondents of $105,82 \%$ were male and $18 \%$ was female. Maximum respondents belonged to an urban population $(60 \%)$ and most of the respondents $(80 \%)$ which are related to the decision of environmental cases a good number were lawyers (61.2).about half (49\%) of the learners had computer access out of which $20.4 \%$ had it at work place and only $18.4 \%$ had it at home. Others were using computer facility at cyber café (10.2\%).most of respondents (65.3)had prior knowledge of rules of law and other important process of judiciary.

\section{Environmental Cases and Environmental courts}

The opinion of the judiciary experts regarding environmental cases in general, case objectives, judiciary work, strengthening of pollution control board and comparative experience in particular was sought on five point scale: from strongly disagree (1) to strongly agree (5) and is given in table 1.the arability mean for most of the items were high (above 3 ) and almost all standard deviations were less than 1.00 or around one. These indicated the most of the respondents had common thought in terms of the indicators listed in table 1.

The data from table 1 clearly indicates that judiciary experts found such kind of court will be quite motivating and they can solve environmental cases with the help of MOEF (ministry of environment and forests) nodal agency for the co-ordination of the programs throughout the country. Judiciary experts also agreed the need for the inclusion of a specialized court and also to the creation of interactive package to further enhance the understanding and comprehension of the cases given by the courts.

As regards promoting appellate environmental bodies, the majority of experts found this is very useful and opined that this provided a good opportunity for the decision of the environmental cases. However, the lawyers and others are not very much satisfied with the procedure of handling the environmental cases. Judiciary experts advocated for keeping training of distinct judges compulsory, and they found the specialized court is very useful for solving the cases.

These findings are further supported by the analysis of open ended questions and are placed below.

\section{Judiciary Expert's Views}

Workload and degree of difficulty: The judiciary expert's had an item asking for the hours spent in handling cases in order to clinch the workload requirement in the courts. Most of the lawyers were taking time equal to 8 for 10 hours to study an environment case. Taking an average of 9 hours, a block containing four units would need 36 hours. This translates into a total of 144 hours for the whole case having 4 blocks, which indicates that they are spending more time than stipulated.

On the average, about 60 percent of the respondent's required trained distinct judges, which indicates a high difficulty level for all the blocks; block 3 being most difficult (65.3\%).correlation of training of distinct judges with the environmental cases.

Majority of respondents either strongly agreed (SA) or agreed (A) that there is coherence and correlation between training of judges and the environmental cases. 


\section{Data analysis}

A very good percentage of the respondents have given a positive response for the item on "whether they attempted the self assessment questions given at the end of each section or subsection". The block wise percentage is 79.6, $83.7,75.5$, and 81.6 , to block $1,2,3$ and 4 respectively.

Majority of the respondents opined for an adequate environmental court for handling the environmental related cases. In each block as indicated by the percentage 77.6, 81.6, 85.7 and 83.7 for block 1, 2, 3 and 4 respectively. There was no response to the specific difficulties faced and any other mistake for each of the units faced in spite of listening them as items in the questionnaire. Majority (71.4\%) of the learners strongly agreed or agreed for global law along with the global rules.

\section{Looking Forward}

In view of the above, the establishment of special environmental court in India seems to be burning stages rather than a matter of urgency. Therefore, I suggest that the due circumstances for establishing special environmental court in India are not yet demanding, and India must undergo full review for its' environmental legislations and judicial structure before deciding the issue of establishing special courts in general and environmental court in particular. Until then, India may specify certain juries in the existing ordinary courts to review environmental litigation as well as environmental offenses. These juries will certainly alleviate complications associated with environmental litigations, besides that, they will serve as a kernel for any future environmental court.

\section{Recommendations}

1. In view of the involvement of complex scientific and specialized issues relating to environment, there is a need to have separate 'Environment Courts' manned only by the persons having judicial or legal experience and assisted by persons having scientific qualification and experience in the field of environment.

2. In order to achieve the objectives of accessible, quick and speedy justice, these 'Environment Courts' should be established and constituted by the Union Government in each State.

3. The proposed Environment Court should consist of a Chairperson and at least two other members.

4. The proposed Environment Court shall also have appellate jurisdiction.

5. Global law is necessary to solve the environmental cases and 12 law of principle is helpful for the better judiciary process.

\section{References}

Cardozo, N. Benjamin. (2000). THE NATURE OF THE JUDICIAL PROCESS, Universal Law Publication, 3rd Indian Reprint, p.18-19.

D Farrier \& L.Fisher. (1993). Reconstituting Decision Making Process and Structures in Light of the Precautionary Principal. Paper presented at the Precautionary Principle Conference, University of New South Wales, and September

D, Sean Murphy. (2000). Does the World Need a New International Environmental Court? 32 The George Washington Journal of International Law and Economics. 333

Dharmadhikari, D.M. Justice. (2004). Principle of Constitutional Interpretation: Some Reflections, 4 SCC (Jour) 1

Ghosh, Subha Soura. (2008). Sustainable Development and Indian Judiciary, http://www.legalserviceindia.com/articles/jud.htm

Hoelting, A. Rebecca. (1994). After Rio: The Sustainable Development Concept Following The United Nations Conference on Environment And Development. 24 Ga. J. Int'l \& Comp. L.

Karthik, A. S. (2006). The Doctrine of Public Trust and Environmental Protection in India" http://www.nlsenlaw.org/environmentalprotection/articles/the-doctrine-of-public-trust-and-environmentalprotect ion-in-india/

Kirpal, B.N Justice. (2002). Environmental Justice In India, 7 SCC (Jour) 1.

Lee, Maria. (2006). Legal Studies. Tort, regulation and environmental Liability, Volume 22, Issue 1

Oaks, L. James. (2004). The Judicial Role in Environmental Law, 52 NYU L. Rev. 498, 512.

Rio from Road the. (1993). An Interview with Norway Prime Minister GroHarlem Bruntland, Tech. Rev., April.

Sabarwal, Y.K Justice Former CJI. (2006). Hon'ble Role of Judiciary In Striking The Right Balance: Evolving Paradigms of Jurisprudence, International Conference on Striking The Right Balance: Law And Sustainable 
Development In India's Energy $\quad$ Economy, NewDelhi,heldon7-8July http://supremecourtofindia.nic.in/new_links/CII.doc.

Stein. L. (2000). Are Decision-makers too Cautious with the Precautionary Principal? Volume 17, Environment and Planning Law Journal 3.

Tope, K.T. (1988). Supreme Court of India and Social Jurisprudence, 1 SCC.

Weiss, Brown Edith. (1984). The planetary Trust: Conservation and Intergenerational Equity, 11 Ecology L.Q.495, 538 .

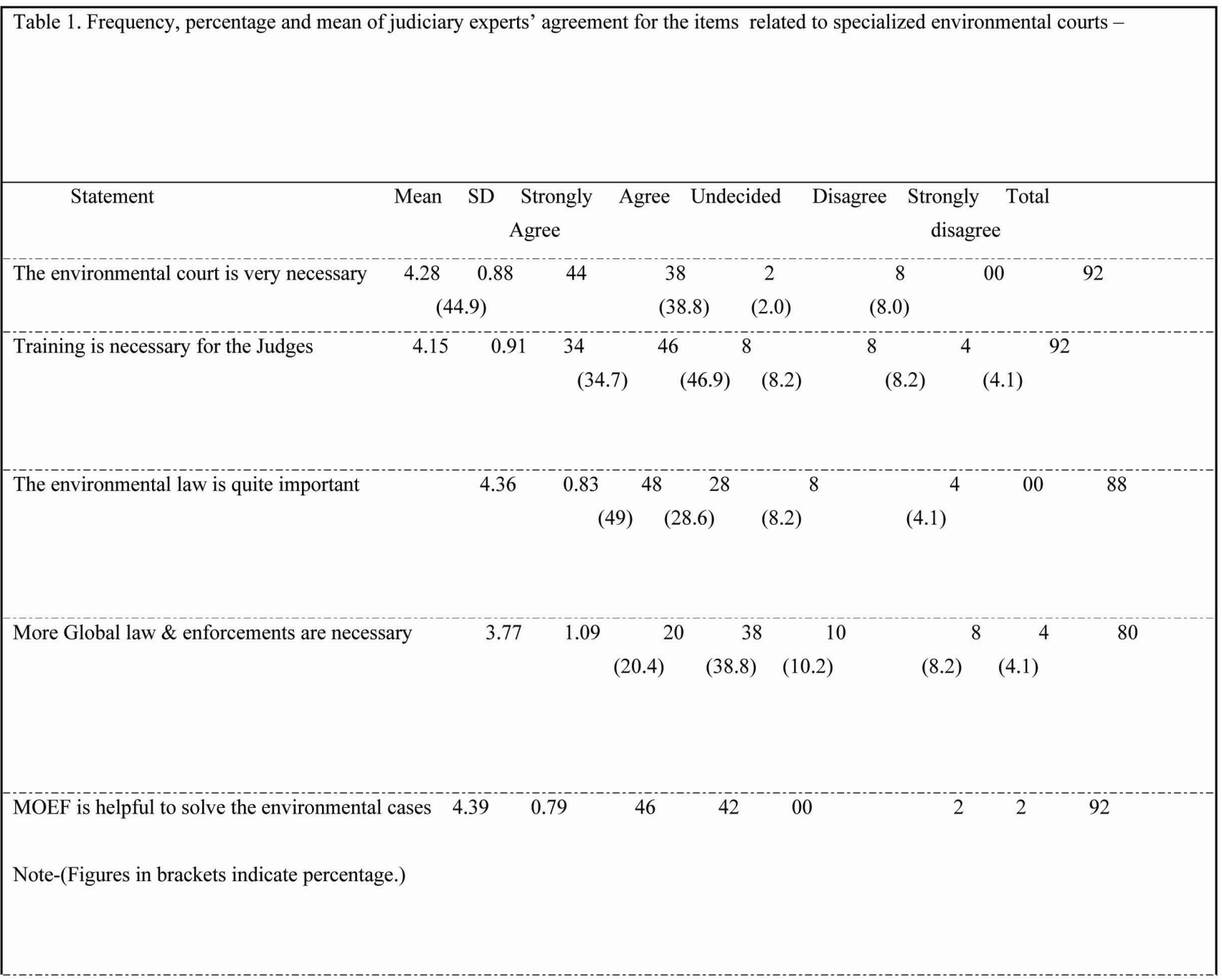

